\title{
EFFICACY OF SOFOSBUVIR IN INTERFERON TREATED PATIENTS OF HEPATITIS C INFECTED WITH 3A GENOTYPE.
}

\footnotetext{
1. MS Chemistry Department of Chemistry University of Management and Technology, Lahore.

2. MBBS

House Officer Department of Internal Medicine KEMU, Mayo Hospital, Lahore.

3. MBBS, FCPS

Assistant Professor

Department of Pathology KEMU, Mayo Hospital, Lahore.

4. MBBS

House Officer

Department of Internal Medicine KEMU, Mayo Hospital, Lahore.

5. PhD.

Associate Professor

Department of Life Sciences

University of Management and

Technology, Lahore.

6. MBBS, FCPS

Assistant Professor

Department of Gynaecology and Obstetrics

Gujranwala Medical College,

DHQ Teaching Hospital, Gujranwala.
}

Correspondence Address:

Dr. Samreen Hameed

House No.325, B Block,

PCSIR, Phase-II, Lahore.

sultanulmoazzam265@gmail.com

Article received on:

19/11/2018

Accepted for publication:

25/03/2019

Received after proof reading:

$30 / 09 / 2019$

\begin{abstract}
Saroosh Zahoor ${ }^{1}$, Sarmad Zahoor ${ }^{2}$, Samreen Hameed ${ }^{3}$, Syed Maaz Abdullah ${ }^{4}$, Mohammad Sohail Afzal ${ }^{5}$, Uzma Butt ${ }^{6}$
\end{abstract}

ABSTRACT... Objectives: Hepatitis $C$ is a blood borne infection primarily disrupting the functional and architectural integrity of liver and has a considerable share in worldwide mortality and morbidity. Treatment strategies against the causative RNA-based virus has widely evolved over time with newer Direct Acting Antivirals (DAA) being recently introduced. This study serves to assess the efficacy of Sofosbuvir (DAA) in patients of HCV genotype 3a with prior treatment with interferon. Study Design: An Open label, Prospective Quasi Experimental Study. Setting: Mayo Hospital, Lahore. Period: September 2016 to December 2017. Material and Methods: 212 patients with genotype $3 \mathrm{a}$ who had been previously treated with interferon (INF). They were treated with Sofosbuvir 400mg once daily and Ribavirin 400mg thrice daily. The treatment duration was 24 weeks following which the end of treatment response (ETR) was determined by quantifying viral load by Polymerase Chain Reaction (PCR). Results: Of the 212 patients enrolled, 50 patients did not give follow up either due to availability issues or due to noncompliance. 13 patients left the treatment due to comorbidities. 149 patients completed the treatment out of whom 131 patients showed positive response (87.9\%). Nine patients with high viral load showed relapse while nine patients were non-responders. Conclusion: In interferon experienced patients of HCV genotype $3 a$, Sofosbuvir has shown to reach sublimecure rates which may serve to obviate conventional treatment strategies owing to their longer treatment duration and significant adverse effects. As demonstrated by this study, the modest safety profile coupled with an enhanced therapeutic efficacy of Sofosbuvir is expected to revolutionize treatment strategies against Hepatitis $\mathrm{C}$ limiting the spread and hence the incidence of disease.

Key words: $\quad$ Genotype 3a, Hepatitis C, Interferon Treated Patients, Sofosbuvir.

Article Citation: Zahoor S, Zahoor S, Hameed S, Abdullah SM, Afzal M, Butt U. Effectiveness of sofosbuvir in interferon treated patients of hepatitis $\mathrm{C}$ infected with $3 \mathrm{a}$ genotype. Professional Med J 2019; 26(10):1606-1612.

DOI: 10.29309/TPMJ/2019.26.10.1225

\section{INTRODUCTION}

Hepatitis C, a disease that causes destruction of the structural and functional capacity of the liver, is caused by a virus belonging to family Flaviviridae, genus Hepacivirus and species Hepatitis $C$ virus; it has six genotypes with $3 a$ being most common in Pakistan. . $2,3,4$ Hepatitis C can be acute, chronic or self-resolving in $15-45 \%$ of cases. ${ }^{5}$ It is transmitted mainly through body fluids along with vertical transmission during pregnancy as well. ${ }^{6,7}$ Hepatitis C exhibits mutation in its nucleotide, genotype and sub-genotypes with rates being $1-5 \%, 30-50$ and $15-30 \%$ respectively. ${ }^{8}$ The reasons for mutation may be various, with lack of proofreading and rapid rate of replication being noteworthy. ${ }^{9}$ Genome of HCV contains structural proteins(core proteins: E1, E2) and nonstructural proteins (NS1-5) out of which NS5A possesses a region known as interferon-alpha sensitivity determining region (ISDR) that helps to develop resistance to interferon through repression of PKR Protein kinase. 10,11,12,13,14 Acyclovir(an anti-viral) was initially tried for the treatment of hepatitis, but with little success. ${ }^{15}$ INF-alpha(an antiviral cytokine), when given for 24 weeks, showed positive response with an SVR of 6\%- this doubled with the doubling of treatment duration. ${ }^{16,17,18}$ Ribavirin, an antiviral agent approved by WHO in 1972, was previously used as monotherapy to treat hepatitis $C$, but it happened to lower ALT level but not viral load..$^{19,20,21}$ Ribavirin, when used with INF-alfa for 24 weeks, showed an improved SVR 
of $24 \%$ which was doubled by doubling therapy duration. ${ }^{22}$ FDA approved this combination of drugs and duration for genotype $3 a$ in $1998 .{ }^{23}$ The factors that determine the efficacy of INFbased treatment of HCV patients are cirrhosis, hepatic steatosis, host's genetic variation in IL28B, gender, obesity, non-response to previous interferon-based therapy, age, ethnicity, insulin resistance, HCV genotype, HCV load and coinfection with $\mathrm{HIV}^{24}$ Since the duration of this therapy was long and hard to tolerate, dosage for INF-alfa was decreased by increasing its halflife through pegylation (INF + Inert compound) which showed a higher SVR than before (39\%) which later proved to be 54 to $56 \%$ after combining it with ribavirin for 48 weeks. ${ }^{25}$ This combination was approved by FDA for genotype $3 a$ for 24 weeks. ${ }^{26}$ In the next step direct acting antivirals (DAA) were used which proved to be comparatively safer and more effective. These were Simeprevir (HCV Protease Inhibitor), Declatasvir (HCV NS5A Inhibitor), and Sofosbuvir (HCV NS5B Polymerase inhibitor). ${ }^{27,28}$ Sofosbuvir is a nucleoside analogue and inhibits replication of HCV RNA. ${ }^{29}$ FDA approved it with ribavirin for 24 weeks for genotype $3 a .^{30}$ Feld et al found SVR for genotype $3 a$ with Sofosbuvir to be $88 \%$ in noncirrhotic pretreated patients. ${ }^{31}$ VALENCE study of Europe found SVR of $85 \%$ for genotype $3 a{ }^{32} \mathrm{~A}$ recent study in Pakistan at Rawalpindi showed an SVR of $96.5 \%$ with SOF+RBV for genotype $3 a^{33}$ Another study named RESiP in Pakistan involving 94\% 3a patients showed an SVR of $86 \%$ in INF experienced patients. ${ }^{34}$ There is lack of data on the efficacy of Sofosbuvir in 3a genotype especially for those who have been already treated with INF. Here our study provides an evidence of its efficacy which will be very useful for its future use in INF experienced patients of HCV.

\section{AIMS AND OBJECTIVES}

1. Analyzing the efficacy of Sofosbuvir in HCV patients infected with 3 a genotype who have had interferon treatment.

2. To study different factors that affect the efficacy of Sofosbuvir

\section{MEHODOLOGY}

\section{Study Design}

Open label, Prospective Quasi Experimental study.

\section{Setting}

Mayo Hospital, Lahore.

\section{Study Duration}

September 2016 to December 2017.

Patients of age b/w 20 to 70 years infected with HCV genotype 3a who had previously been treated with INF and did not have decompensated chronic liver disease (confirmed by USG-Abdomen and signs and symptoms of decompensation) were included. HIV negative Pakistani nationals were enrolled after taking informed consent. All patient infected with HCV genotype other than 3 a or age greater than 70 or less than 20 or with DCLD or HIV positive patients or patients of HCV $3 a$ having foreign nationality were excluded. Serum AST and ALT levels of the patients were determined at the start of study by measuring the rate of consumption of NADH in their respective reactions spectrophotometrically. Commercially made kits were used for this purpose. Serum creatinine level was also determined based on Jaffe's method which measured rate of formation of orange yellow creatinine-picrate complex, the concentration of which was proportional to creatinine in serum sample at beginning of study. Real Time Quantitative PCR and PCR Genotype were also done at the start of treatment. Patients were followed up for 24 weeks of treatment for any adverse event and to ensure compliance and a quantitative PCR was also performed at the end of 24 weeks in order to determine response of therapy at the end (end of treatment response i.e. ETR). History to probe cause of HCV was taken. Patient was asked about history of blood transfusion, IV drug abuse or family history of his/ her partner being HCV positive. Co-morbidities if present in any patient were recorded as well. All patients were given Sofosbuvir 400mg one tablet in a day and Ribavirin 400mg one tablet three times a day. Data was analyzed using SPSS 20. 


\section{RESULTS}

In this study 212 patients infected with genotype 3a were enrolled in which 50 patients left and did not give follow up for following reasons: 30 patients belonged to far off outskirts of the country and were not able to report back while20 patients were non-compliant. 162 patients continued the therapy out of which 13 patients discontinued due to comorbidities and 149 patients completed the therapy i.e. 24 weeks.

Results of this study came out to be: $131 / 149$ $(87.9 \%)$ patients showed positive response out of which 51 (38.9\%) were males and 80 (61\%) were females.

\section{Summary of patients enrolled}

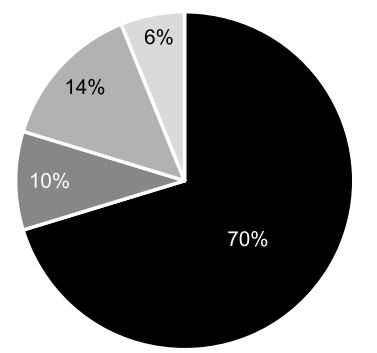

Patients who completed the treatment Patients who were non-compliant Patients who had availability issues Patients who left due to comorbidities

Considering $8 \times 10^{5} \mathrm{IU} / \mathrm{ml}$ or above as high viral load, nine patients showed relapse and all had high viral load. One patient relapsed at 6 weeks, two of them after 8 weeks and six after 12 weeks. The reason of their relapse was not identified but it was thought that it might be due to mutation in NS5B polymerase.

There were nine patients who were nonresponders. Two of them had low viral load while rest of them had high viral load. Two patients showed features of decompensated chronic liver disease (DCLD) on USG. Five patients were noncompliant. Two patients were non-responders with the reason being unknown.

8 patients discontinued the treatment due to fatigue, myalgia, marked pallor and weight loss. One patient left the therapy due to congestive heart failure. Two patients discontinued due to cancer. One known diabetic and hypertensive patient discontinued the treatment due to pedal edema and pallor. One diabetic patient left the treatment due to chronic kidney disease (CKD) and anemia.

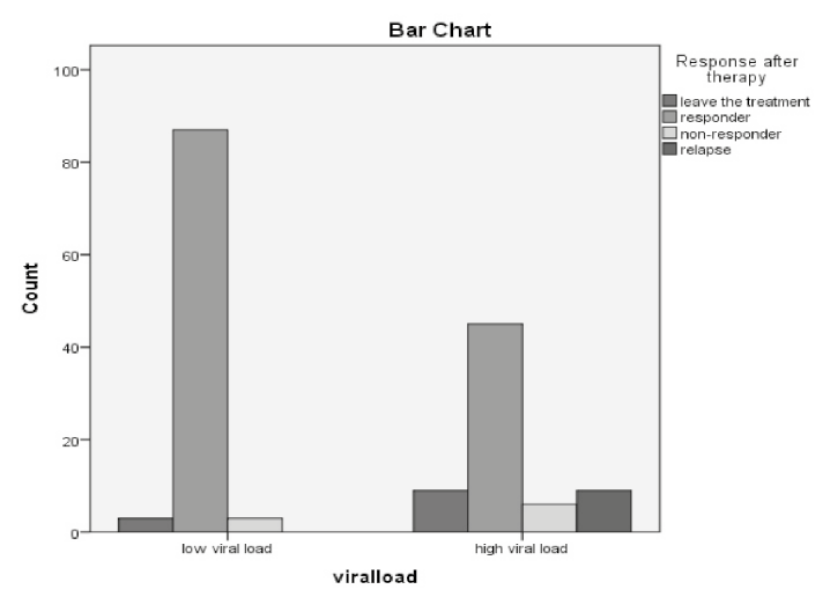

P-value came out to be significant $(<0.005)$.

Average of all patients' age, ALT, AST, viral load and creatinine level were $46.54( \pm 9.59$ years), $72.28( \pm 42.73 \mathrm{IU} / \mathrm{l}), 78.01( \pm 50.23 \mathrm{IU} / \mathrm{l})$, $15146523( \pm 5205719 \mathrm{lU} / \mathrm{mL})$ and $0.8( \pm 0.3 \mathrm{~g} / \mathrm{dL})$ respectively. History of the patients revealed that $32(19.7 \%)$ patients were drug abusers and all were males. $29(17.9 \%)$ had HCV positive partner in which $12(7.4 \%)$ were males and $17(10.5 \%)$ were females. $55(33.9 \%)$ patients had a history of blood transfusion in which $15(9.24 \%)$ were males and $40(24.66 \%)$ were females.

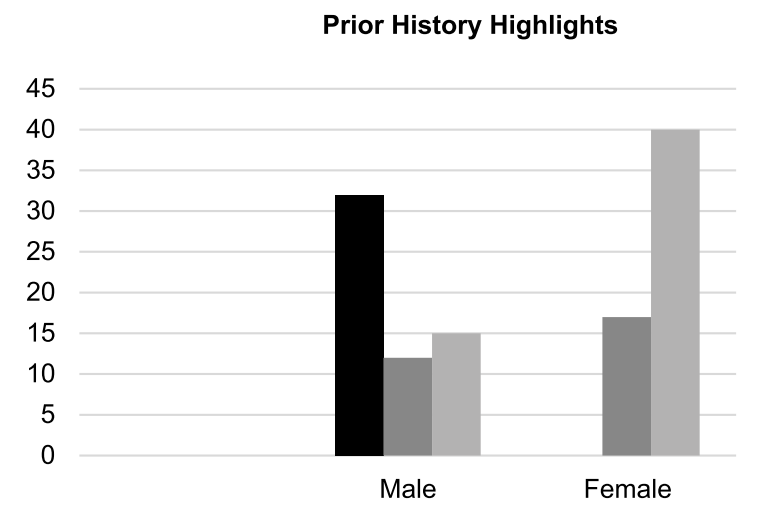

IV Drug Abuse HCV positive partner Blood transfusion(s)

\section{DISCUSSION}

$\mathrm{HCV}$, a threat to the globe, mainly affects liver and has led millions to death with mortality rate still on the rise necessitating the need to devise effective treatment. After trying acyclovir 
and ribavirin as monotherapy, the problem was somewhat catered with by using INF and RBV in combination. The treatment was further improved by use of pegylated INF. Still side effects of this combination were a much bigger problem hampering patients' compliance. DAA revolutionized the treatment of hepatitis $C$ out of which the one primarily used was pan-genotypic polymerase inhibitor, Sofosbuvir.

SOF, approved by FDA in 2013, proved to be very effective for HCV. Efficacy of Sofosbuvir against genotype 1 was abundantly documented in Western population but its activity against genotype 3 (common in the East) was only proven in a few trials the notable ones being FISSION, FUSION, POSITRON, ALLY-3 and BOSSON trial. The results of these trials proved it to be very effective both in treatment-naïve and INF experienced patients. ${ }^{35-39}$ VALENCE trial showed an SVR of $77 \%$ in INF experienced patients of genotype $3 a$. An important study of Pakistan RESiP trial that involved $94 \%$ of patients of $3 a$ showed an SVR of $86 \%$ in INF experienced patients. In our study, 162 patients were included of which 149 completed therapy (24 weeks). The response after therapy was $87.9 \% \%$. Results of previous studies were very close to it. There were 9 patients who showed relapse. Relapse was due to mutation or reinfection by HCV with no role of INF resistance in it since it did not seem to be related to non-structural proteins. ${ }^{40}$ There were 9 patients who were non-responders the precise reason of which was not known.

Various studies indicated that INF treated female patients of age 50 or greater showed high SVR than male patients due to gender disparity. So in this study similar results were found. ${ }^{41,42}$

There were 13 patients who discontinued the therapy. Discontinuation of therapy was mainly due to either side effects of the drugs or any other co-morbidity that imposed additional stress on the patient and led to inability to tolerate the therapy. So, in order to improve the compliance of the patient, acute events and side effects need to be managed properly along with patient's education.
SOF proved to be very effective for $\mathrm{HCV}$ in combination with other DAA. A recent study showed that $86 \%$ efficacy of SOF plus Declatasvir for 12 weeks in INF experienced patients of $3 a$ (37). Another result for this regimen was $89 \%$ SVR in another trial. ${ }^{43}$ SVR could be increased by increasing duration of treatment. The use of SOF and other DAA and their therapy duration was not well known for HCV GT-3a patients. So, it was an unsolved issue and needed more work on it. Another issue was relapse of INF treated patients after taking complete therapy of SOF plus RBV. Through this research, we have tried to reflect on both the issues and give an insight on the expected outcome.

Copyright $(25$ Mar, 2019.

\section{REFRENCES}

1. Petruzziello, A., Marigliano, S., Loquercio, G., Cozzolino, A., \& Cacciapuoti, C. (2016). Global epidemiology of hepatitis C virus infection: An up-date of the distribution and circulation of hepatitis $\mathrm{C}$ virus genotypes. World Journal of Gastroenterology, 22(34), 7824.

2. Rosen, H. R. (2011). Chronic hepatitis C infection. New England Journal of Medicine, 364(25), 2429-38.

3. Simmonds, P., Bukh, J., Combet, C., Deléage, G., Enomoto, N., Feinstone, S., \& Mizokami, M. (2005). Consensus proposals for a unified system of nomenclature of hepatitis $\mathrm{C}$ virus genotypes. Hepatology, 42(4), 962-73.

4. Simmonds, P., Holmes, E. C., Cha, T. A., Chan, S. W., McOmish, F., Irvine, B., \&Urdea, M. S. (1993). Classification of hepatitis $C$ virus into six major genotypes and a series of subtypes by phylogenetic analysis of the NS-5 region. Journal of General Virology, 74(11), 2391-99.

5. Lozano R, Naghavi M, Foreman K, Lim S, Shibuya K, Aboyans V, Abraham J, Adair T, Aggarwal R, Ahn SY, AlMazroa MA. Global and regional mortality from 235 causes of death for 20 age groups in 1990 and 2010: a systematic analysis for the Global Burden of Disease Study 2010. The lancet. 2012 Dec 15;380(9859):2095128.

6. Wise, M., Bialek, S., Finelli, L., Bell, B. P., \&Sorvillo, F. (2008). Changing trends in hepatitis C-related mortality in the United States, 1995 $\square$ 2004. Hepatology, 47(4), 1128-35. 
7. Afzal MS, Shah ZH, Ahmed H. Recent HCV genotype changing pattern in the Khyber Pakhtunkhwa province of Pakistan; is it pointing out a forthcoming problem?. Brazilian Journal of Infectious Diseases. 2016 Jun;20(3):312-3.

8. Bukh J, Purcell RH, Miller RH. Sequence analysis of the core gene of 14 hepatitis $C$ virus genotypes. Proceedings of the National Academy of Sciences. 1994 Aug 16;91(17):8239-43.

9. Echeverría N, Moratorio G, Cristina J, Moreno P. Hepatitis $\mathbf{C}$ virus genetic variability and evolution. World journal of hepatology. 2015 Apr 28;7(6):831.

10. Hijikata M, Mizushima H, Akagi T, Mori S, Kakiuchi N, Kato N, Tanaka T, Kimura K, Shimotohno K. Two distinct proteinase activities required for the processing of a putative nonstructural precursor protein of hepatitis C virus. Journal of virology. 1993 Aug 1;67(8):4665-75.

11. Penin F, Dubuisson J, Rey FA, Moradpour D, Pawlotsky JM. (2004). Structural biology of hepatitis C virus. Hepatology, 39(1), 5-19.

12. Lindenbach BD, Thiel HJ, Rice CM. Fields virology. Edited by: Knipe DM, Howley PM. Lippincott-Raven, Philadelphia. 2007.

13. Gale Jr MJ, Korth MJ, Tang NM, Tan SL, Hopkins DA, Dever TE, Polyak SJ, Gretch DR, Katze MG. Evidence that hepatitis $C$ virus resistance to interferon is mediated through repression of the PKR protein kinase by the nonstructural 5A protein. Virology. 1997 Apr 14;230(2):217-27.

14. Enomoto N, Sakuma I, Asahina Y, Kurosaki M, Murakami T, Yamamoto C, Izumi N, Marumo F, Sato C. Comparison of full-length sequences of interferon-sensitive and resistant hepatitis $C$ virus $1 \mathrm{~b}$. Sensitivity to interferon is conferred by amino acid substitutions in the NS5A region. The Journal of clinical investigation. $1995 \mathrm{Jul}$ 1;96(1):224-30.

15. Pappas SC, Hoofnagle JH, Young N, Straus SE, Jones EA. Treatment of chronic non-A, non-B hepatitis with acyclovir: Pilot study. Journal of medical virology. 1985 Jan;15(1):1-9.

16. Wohnsland A, Hofmann WP, Sarrazin C. Viral determinants of resistance to treatment in patients with hepatitis C. Clinical Microbiology Reviews. 2007 Jan 1;20(1):23-38.

17. Feld JJ, Hoofnagle JH. Mechanism of action of interferon and ribavirin in treatment of hepatitis $\mathbf{C}$. Nature. 2005 Aug 17;436(7053):967.
18. Davis GL, Balart LA, Schiff ER, Lindsay K, Bodenheimer Jr HC, Perrillo RP, Carey W, Jacobson IM, Payne J, Dienstag JL, VanThiel DH. Treatment of chronic hepatitis $\mathbf{C}$ with recombinant interferon alfa. New England journal of medicine. 1989 Nov 30;321(22):15016.

19. Sidwell RW, Huffman JH, GP Khare L, Allen B, JT Witkowski R, Robins K. Broad-spectrum antiviral activity of virazole: 1-f8-D-ribofuranosyl-1, 2, 4-triazole-3-carboxamide. Science. 1972 Aug 25;177(4050):705-6.

20. Snell NJ. Ribavirin-current status of a broad spectrum antiviral agent. Expert opinion on pharmacotherapy. 2001 Aug 1;2(8):1317-24.

21. Dusheiko G, Main J, Thomas H, Reichard O, Lee C, Dhillon A, Rassam S, Fryden A, Reesink H, Bassendine $M$, Norkrans $G$. Ribavirin treatment for patients with chronic hepatitis $\mathrm{C}$ : results of a placebo-controlled study. Journal of hepatology. 1996 Nov 1;25(5):591-8.

22. Poynard T, Marcellin P, Lee SS, Niederau C, Minuk GS, Ideo G, Bain V, Heathcote J, Zeuzem S, Trepo C, Albrecht $\mathrm{J}$. Randomised trial of interferon $\mathrm{a} 2 \mathrm{~b}$ plus ribavirin for 48 weeks or for 24 weeks versus interferon $a 2 b$ plus placebo for $\mathbf{4 8}$ weeks for treatment of chronic infection with hepatitis C virus. The Lancet. 1998 Oct $31 ; 352(9138): 1426-32$.

23. Mangia A, Santoro R, Minerva N, Ricci GL, Carretta V, Persico M, Vinelli F, Scotto G, Bacca D, Annese M, Romano M. Peginterferon alfa-2b and ribavirin for 12 vs. 24 weeks in HCV genotype 2 or 3 . New England Journal of Medicine. 2005 Jun 23;352(25):2609-17.

24. Chen $\mathrm{CH}, \mathrm{Yu} \mathrm{ML}$. Evolution of interferon-based therapy for chronic hepatitis C. Hepatitis research and treatment. 2010;2010.

25. Reddy KR, Wright TL, Pockros PJ, Shiffman M, Everson G, Reindollar R, Fried MW, Purdum III PP, Jensen D, Smith C, Lee WM. Efficacy and safety of pegylated (40-kd) interferon a-2a compared with interferon a-2a in noncirrhotic patients with chronic hepatitis C. Hepatology. 2001 Feb 1;33(2):433-8.

26. Strader DB, Wright T, Thomas DL, Seeff LB. Diagnosis, management, and treatment of hepatitis $C$. Hepatology. 2004 Apr;39(4):1147-71.

27. Jesudian AB, Gambarin-Gelwan M, Jacobson IM. Advances in the treatment of hepatitis $C$ virus infection. Gastroenterology \& hepatology. 2012 Feb;8(2):91. 
28. Stedman CA. Current prospects for interferonfree treatment of hepatitis $C$ in 2012. Journal of gastroenterology and hepatology. 2013 Jan;28(1):3845.

29. Yamashita T, Kaneko S, Shirota Y, Qin W, Nomura T, Kobayashi K, Murakami S. RNA-dependent RNA polymerase activity of the soluble recombinant hepatitis C virus NS5B protein truncated at the C-terminal region. Journal of Biological Chemistry. 1998 Jun 19;273(25):15479-86.

30. Food and drug administration. (2013). SOVALDI (sofosbuvir) tablets, for oral use. Retrieved from: http://www.accessdata.fda.gov/drugsatfda_docs/ label/2013/2 04671s000lbl.pdf.

31. Feld JJ, Maan R, Zeuzem S, Kuo A, Nelson DR, Di Bisceglie AM, Manns MP, Sherman K, Frazier LM, Sterling $R$, Mailliard M. Effectiveness and safety of sofosbuvirbased regimens for chronic HCV genotype 3 infection: results of the HCV-TARGET Study. Clinical Infectious Diseases. 2016 Jun 19;63(6):776-83.

32. Zeuzem S, Dusheiko GM, Salupere R, Mangia AD, Flisiak $\mathrm{R}$, Hyland $\mathrm{RH}$, Illeperuma A, Svarovskaia ES, Brainard DM, Symonds WT, McHutchison JG. Sofosbuvir plus ribavirin for 12 or 24 weeks for patients with HCV genotype 2 or 3: the VALENCE trial. InHepatology 2013 Oct 1 (Vol. 58, pp. 733A-734A). WILEY-BLACKWELL.

33. Akhter TS, Umar M, Aslam F, Nisar G, Naseer A, Ahmad $\mathrm{S}$, Osama M. Sofosbuvir for the treatment of hepatitis C genotype 3 infected patients in Pakistan. Journal of Ayub Medical College Abbottabad. 2017 Feb 1;28(4 Sup):884-9.

34. Farooqi Jl, Humayun M, Chaudhry A, Sadik M, Din Z, Alam A, et al. Multi-center experience using Sofosbuvir \& Ribavirin with and without pegylated interferon to treat hepatitis $\mathbf{C}$ patients with and without liver cirrhosis (RESiP Study: Real-life Experience with Sofosbuvir in Pakistan). [abstract accepted for AASLD 2016 \#2548704].

35. Lawitz E, Mangia A, Wyles D, Rodriguez-Torres M, Hassanein T, Gordon SC, Schultz M, Davis MN, Kayali Z, Reddy KR, Jacobson IM. Sofosbuvir for previously untreated chronic hepatitis $\mathbf{C}$ infection. New England Journal of Medicine. 2013 May 16;368(20):1878-87.
36. Jacobson IM, Gordon SC, Kowdley KV, Yoshida EM, Rodriguez-Torres M, Sulkowski MS, Shiffman ML, Lawitz E, Everson G, Bennett M, Schiff E. Sofosbuvir for hepatitis $\mathbf{C}$ genotype 2 or 3 in patients without treatment options. New England Journal of Medicine. 2013 May 16;368(20):1867-77.

37. Nelson DR, Cooper JN, Lalezari JP, Lawitz E, Pockros PJ, Gitlin N, Freilich BF, Younes ZH, Harlan W, Ghalib $R$, Oguchi G. All-oral 12-week treatment with daclatasvir plus sofosbuvir in patients with hepatitis C virus genotype 3 infection: ALLY-3 phase III study. Hepatology. 2015 Apr;61(4):1127-35.

38. Foster GR, Pianko S, Brown A, Forton D, Nahass RG, George J, Barnes E, Brainard DM, Massetto B, Lin M, Han B. Efficacy of sofosbuvir plus ribavirin with or without peginterferon-alfa in patients with hepatitis $C$ virus genotype 3 infection and treatmentexperienced patients with cirrhosis and hepatitis C virus genotype 2 infection. Gastroenterology. 2015 Nov 1;149(6):1462-70.

39. Mangia A, Piazzolla V. Overall efficacy and safety results of sofosbuvir-based therapies in Phase II and III studies. Digestive and Liver Disease. 2014 Dec 15;46:S179-85.

40. Hiet MS, Bauhofer O, Zayas M, Roth H, Tanaka Y, Schirmacher P, Willemsen J, Grünvogel O, Bender S, Binder M, Lohmann V. Control of temporal activation of hepatitis $C$ virus-induced interferon response by domain 2 of nonstructural protein $5 A$. Journal of hepatology. 2015 Oct 1;63(4):829-37.

41. Belci, P., Collo, A., Martorana, M., Evangelista, A., Giunti, S., Gambino, R., \&Durazzo, M. Can gender predict virological response to standard antiviral therapy for chronic hepatitis C: A retrospective study. Hepatoma Res 2016;2:122-30.

42. Ruggieri A, Malorni W. Gender disparity in hepatitis: a new task in the challenge against viral infection. $J$ Hepat Res. 2015;2(3):1028.

43. Cholongitas E, Papatheodoridis GV. Sofosbuvir: a novel oral agent for chronic hepatitis C. Annals of Gastroenterology: Quarterly Publication of the Hellenic Society of Gastroenterology. 2014;27(4):331. 


\begin{tabular}{|c|c|c|c|}
\hline \multicolumn{4}{|c|}{ AUTHORSHIP AND CONTRIBUTION DECLARATION } \\
\hline Sr. \# & Author-s Full Name & Contribution to the paper & Author's Signature \\
\hline 1 & Saroosh Zahoor & Drafting manuscript. & biancer \\
\hline 2 & Sarmad Zahoor & Writing and analyzing the data. & \\
\hline 3 & Samreen Hameed & $\begin{array}{l}\text { Reviewed the article and helped } \\
\text { analyzing data. }\end{array}$ & \\
\hline 4 & Syed Maaz Abdullah & Data collection and editing. & \\
\hline 5 & M. Sohail Afzal & $\begin{array}{l}\text { Supervised and reviewed the } \\
\text { study. }\end{array}$ & \\
\hline 6 & Uzma Butt & Strongly reviewed the article. & \\
\hline
\end{tabular}

